\title{
Effectiveness of Project-based Learning Models to Improve Learning Outcomes and Learning Activities of Students in Innovative Learning
}

\section{Susanti, Joni Susilowibowo, and Han Tantri Hardini}

Faculty of Economics, Universitas Negeri Surabaya, Surabaya, Indonesia

\section{Abstract}

This study aims to determine the effectiveness of Project-based Learning models in achieving cognitive, affective, and psychomotor learning outcomes compared to conventional models in innovative learning courses. In addition, to find out the learning activities of students in the Project-based Learning model compared to the conventional learning models. The research subjects were 43 students of Accounting Education S1 class of 2015. The research approach used was quasi-design experiment, while the

Corresponding Author:

Susanti

susanti@unesa.ac.id

Received: 29 January 2019 Accepted: 27 February 2019 Published: 24 March 2019

Publishing services provided by Knowledge E

(c) Susanti et al. This article is distributed under the terms of the Creative Commons

Attribution License, which permits unrestricted use and redistribution provided that the original author and source are credited.

Selection and Peer-review under the responsibility of the 3rd ICEEBA Conference Committee.

\section{G OPEN ACCESS} design used was non-equivalent control group design. Data collection was done using test instruments and non-test instruments. Data analysis was carried out by descriptive analysis. The results showed that (1) the Project-based Learning model in achieving cognitive learning outcomes was more effective than the conventional models in innovative learning subjects, (2) the Project-based Learning model in achieving affective learning outcomes was more effective than conventional learning models. In innovative learning lesson, (3) Project-based Learning model in achieving psychomotor learning outcomes is more effective than conventional learning models in innovative learning subjects, and (4) student learning activities in Project-based Learning models are more effective than the conventional learning models.

Keywords: cognitive, affective, psychomotor, learning activities, Project-based Learning

\section{Introduction}

The era of globalization demands every party to change the thinking of each party to follow the development of increasingly sophisticated technology. All parties must prepare themselves for this era of globalization. The thing that must be considered by the education world must certainly prepare creative human resources, be able to solve actual problems in life and be able to produce new technologies which are improvements from before. Everyone is required to always learn. Learning is a very basic thing that cannot be separated from the life of every human being. Along with the development of society 
and increasing needs, the government strives to improve the quality of education. Not only the government, but also observers of education including education practitioners, and education personnel including teachers and lecturers try to make new products in the form of teaching materials, learning media, teaching aids and learning resources needed to complement the old learning resources to fit the curriculum the latest. In addition, education experts also continue to carry out various reforms and researches to improve the quality of learning in schools so that improvements occur in all fields of education. The curriculum is also updated as an effort so that students in Indonesia are not far behind with other countries.

To improve the quality of education, educators, namely teachers and lecturers, must also be given trainings, seminars and activities that support their professional competence. Likewise with prospective teacher students. Students majoring in education must be provided with provisions to become professional teacher candidates so that when they graduate from college, they can immediately work in the world of education well. The courses contained in the curriculum are designed to make professional teacher candidates. One of the courses in the education curriculum, especially at Surabaya State University, is the Innovative Learning course.

The Innovative Learning course is a basic course that is the provision for prospective teacher students to explore how to teach and how to teach their students in the future by applying interesting learning models and in accordance with the applicable curriculum. The hope with this course is that students can prepare themselves to make learning plans well so that in the classroom, they can carry out the learning process in accordance with the learning model that has been made. This Innovative learning course is a compulsory subject for educational undergraduate students especially Accounting Education S1 Study Program and as a prerequisite students can attend Field Lecture Practices (PPL) at partner schools. In this course, each student is given provisions to explore student-centered learning models, design learning models and then practice in the classroom to become an Accounting teacher.

In this course, it is expected that each student has the ability to analyze the teaching methods of teachers in schools in accordance with the learning models and methods in schools, design learning scenarios that are in accordance with the syllabus and curriculum that apply in Vocational High Schools made by their respective groups. In the previous semester, a direct learning model was applied with the lecture method, group discussions and the presentation of each group for the learning model applied by the teacher in the school and then analyzed. After that the lecturer gives reinforcement to the results of student discussions and presentations. Based on the observations of 
researchers, this makes students less likely to understand the material contextually than that they also still have difficulty in analyzing and designing learning models that are appropriate to the characteristics of students. This is because students only explore information on how the teacher teaches from examples on the internet and from the results of journal research. This causes the ability of students not in line with expectations. During the lecture only a few students were active while others were only quiet and tended to be passive in class.

To improve student learning outcomes in the learning process of Innovative learning courses, a learning model is needed that can direct active, critical thinking students, as well as develop analytical and evaluation skills and gain contextual experience. Therefore, the learning activities used are contextual learning activities through complex activities with the Project-Based learning model.

Project-based Learning is an approach to instruction that emphasizes 'authentic learning tasks grounded in the personal interests of learners' (Grant, 2009, p. 1). PjBL is a systematic teaching method that engages students in learning knowledge and skills through an extended inquiry process structured around complex, authentic questions and carefully designed products and tasks. The Buck Institute for Education (Markham, 2003, p. 4). According to The George Lucas Educational Foundation (2005) the phases of the Project-based Learning model are as follows:

1. Start With The Essential Question

2. Design a Plant for the Project

3. Create a Schedule

4. Monitor The Student and The Progress of the Project

5. Asses the Outcome

\section{Evaluate The Experience}

There is project at the base of the project-based learning. At the base of the project is students' finding solutions to problems they face in any way and order in the direction of their own will Moreover, this approach supports students in acquiring manual skills and learning more by performing original activities (Chen, 2004).

Project-based learning is seen as an open-ended contextual activity-bases learning form, and is part of the learning process that places a strong emphasis on problem solving as a collaborative effort, which is carried out in the learning process in a certain period. 
The Project-based Learning Model is an innovative learning model, which emphasizes contextual learning through complex activities. Project-based Learning ( $\mathrm{PJBL}$ ) is a learning model that provides opportunities for educators to manage learning in the classroom by involving project work. PjBL can be defined as a learning with long-term activities that involve students in designing, creating, and displaying products to overcome real-world problems.

Project-based Learning "has become so successful in America that one school in Washington is spending $\$ 128$ llion on rebuilding its campus and redesigning its curriculum around the teaching technique" (Wellham, 2013:1). Students take the initiative to launch campaigns in favor of environmental sustainability, bullying and racial discrimination apart from simply solving problems (Boss, 2013). In Ghana, students are protesting against child labor through digital publishing projects, while in Philippines, student videographers try to protect their forests. All around the world, students delve deeply into projects and prove to be excited to participate in similar ventures.

\section{Research Methods}

This research is a quantitative research by giving assignments (projects) to the experimental class conducted on students of the 2015 Accounting Education class of the State University of Surabaya in semester 5 . The sample in this study uses class A totaling 43 students.

In Project-based Learning, students are given the task to make observations at school by taking one sample, namely the accounting teacher at school, then students observe how the teacher teaches in class. Students also observe the RPP that has been made by the teacher. From the results of observation, students were given the project task of analyzing the syntax carried out by the teacher during learning compared to the lesson plans they had made whether it was appropriate and appropriate. The results of the analysis, the report was made and then presented in class, after that at the next meeting students were given the project assignment to design a learning model that was in accordance with the school studied beforehand. After completing the design of the learning model, each group presented their group's design results in the practice of being a teacher.

The data in this study were conducted through observation, tests and questionnaires. Observation is used to obtain data about student activity in the learning process using 
the Project-based Learning model. The test is used to obtain data about learning outcomes in the cognitive, affective and psychomotor domains. Cognitive learning outcomes were obtained from pretest and posttest in the experimental class and control class. Affective learning results in the form of an assessment of student attitudes as long as the learning model is treated. Psychomotor learning outcomes in the form of student practices about scenarios that have been made based on case analysis encountered when observing teachers in school to designing learning models. Learning activities are assessed by the way the lecturer makes observations during learning. While the questionnaire method was used to obtain data about student responses to the implementation of the Project-based Learning model.

The data obtained in the study were analyzed descriptively. In this study problem based learning model is said to be effective if student activities (results of observation, learning scenario design and practice of learning scenario results), and student questionnaire results in high and very high categories more than or equal to $70 \%$. If it is less than $70 \%$ then it is categorized as less effective. The learning outcomes of the experimental class and the control class are compared to find out their effectiveness.

\section{Results and Discussion}

\subsection{Research results of experimental classes (using Project-based Learning models)}

The Project-based Learning Model in the Innovative Learning course was conducted for 9 weeks (9 meetings). In the learning process, each syntax is done well. Determination of the project schedule is determined in the syntax 1 between lecturers and students. After group members are formed, each group determines the school that is used as an observation. School data where observations on the application of innovative learning models and the results obtained from observations can be seen in Table 1 below:

Based results show that students get real experience contextually, students know firsthand how teachers teach, whether it is in accordance with RPP and existing learning model theory. Based on this, it is hoped that it will be able to create meaningful learning for students as future teacher candidates, memorable learning and deeper student understanding due to student involvement in learning problem solving.

Semester Final Examination (UAS) in the Innovative Learning course, becomes a benchmark for students' cognitive learning outcomes. The following is table 2 which 
TABLE 1: School data used as student observations.

\begin{tabular}{|c|c|c|c|c|}
\hline Off & Observed school & $\begin{array}{c}\text { Classroom } \\
\text { teachers }\end{array}$ & $\begin{array}{l}\text { The material } \\
\text { taught }\end{array}$ & $\begin{array}{l}\text { Learning Model } \\
\text { used }\end{array}$ \\
\hline$A$ & SMK N 1 Surabaya & $x$ & $\begin{array}{l}\text { Accounting Basic } \\
\text { Equations }\end{array}$ & Direct Instruction \\
\hline$B$ & $\begin{array}{l}\text { SMK N } 1 \text { Sooko } \\
\text { Mojokerto }\end{array}$ & $X I$ & $\begin{array}{l}\text { Accounting } \\
\text { computer }\end{array}$ & Cooperative STAD \\
\hline C & $\begin{array}{l}\text { SMKS Prapanca } \\
\text { Surabaya }\end{array}$ & $x$ & $\begin{array}{l}\text { Accounting Basic } \\
\text { Equations }\end{array}$ & Direct Instruction \\
\hline$D$ & $\begin{array}{l}\text { SMKN } 1 \text { Taman } \\
\text { Sidoarjo }\end{array}$ & $x$ & $\begin{array}{l}\text { Accounting } \\
\text { computer }\end{array}$ & $\begin{array}{l}\text { Discovery } \\
\text { Learning }\end{array}$ \\
\hline$E$ & $\begin{array}{l}\text { SMK Dr. Soetomo } \\
\text { Surabaya }\end{array}$ & $x$ & $\begin{array}{l}\text { Accounting Basic } \\
\text { Equations }\end{array}$ & $\begin{array}{l}\text { Cooperative } \\
\text { Learning }\end{array}$ \\
\hline $\mathrm{F}$ & $\begin{array}{l}\text { SMKN } 10 \\
\text { Surabaya }\end{array}$ & $X I$ & Income Tax & $\begin{array}{l}\text { Problem Based } \\
\text { Learning }\end{array}$ \\
\hline G & $\begin{array}{l}\text { SMKS Antartika } 2 \\
\text { Sidoarjo }\end{array}$ & $X I$ & $\begin{array}{l}\text { Special Journal of } \\
\text { Trading } \\
\text { Companies }\end{array}$ & Direct Instruction \\
\hline $\mathrm{H}$ & $\begin{array}{l}\text { SMKN } 2 \text { Buduran } \\
\text { Sidoarjo }\end{array}$ & XII & $\begin{array}{l}\text { Manufacturing } \\
\text { Company } \\
\text { Accounting }\end{array}$ & $\begin{array}{l}\text { Problem Based } \\
\text { Learning }\end{array}$ \\
\hline
\end{tabular}

describes the learning outcomes of students with the application of the Project-based Learning Model.

TABLE 2: Student UAS Learning Outcomes with 'Project-based Learning' Model.

\begin{tabular}{ll} 
No. & Category \\
\hline 1 & Very Good \\
\hline 2 & Good \\
3 & Enough \\
4 & Low \\
5 & Very Low
\end{tabular}

\begin{tabular}{|c|}
\hline Value \\
\hline$(85-100)$ \\
$(80-84.99)$ \\
$(70-79.99)$ \\
$(50-69.99)$ \\
$(0-49.99)$ \\
Total \\
\hline
\end{tabular}

$\begin{gathered}\text { Number of } \\ \text { students }\end{gathered}$
9
28
6
-
-
43

\begin{tabular}{|c|}
\hline$\%$ \\
\hline $11.62 \%$ \\
\hline $69.76 \%$ \\
\hline $18.60 \%$ \\
\hline 0 \\
\hline 0 \\
\hline $100 \%$ \\
\hline
\end{tabular}

Based on Table 2 above, it was found that students get grades with very high, high and sufficient categories. Nobody gets low and very low scores.

The following is Table 3 which shows the total learning outcomes starting from the assignment value, participation, UTS, and UAS.

Based on Table 3 above, it can be concluded that students get A grades (as many as 5 students) and A- (30 students), and the rest get a B+ score (8 people). It can be concluded that the Project-based Learning model is effectively applied to Accounting Education Study Program students.

While the value of student learning activities can be shown in Table 4 below: 
TABLE 3: Student learning outcomes with the Learning Model 'Project-based Learning'.

\begin{tabular}{|l|c|c|c|}
\hline No. & Category & Student & $\%$ \\
\hline 1 & A (85-100) & 5 & $11.62 \%$ \\
\hline 2 & A- (80-84.99) & 30 & $69.76 \%$ \\
\hline 3 & B+ (75-79.99) & 8 & $18.60 \%$ \\
\hline 4 & B (70-74.99) & - & \\
\hline 5 & B- (65-69.99) & - & \\
\hline 6 & C+ (60-64.99) & - & $100 \%$ \\
\hline
\end{tabular}

TABLE 4: Student Learning Activities Using ‘Project-based Learning’ models.

\begin{tabular}{|l|l|c|c|c|c|} 
No. & Learning Activity Indicator & \multicolumn{3}{|c|}{ Experiment Class Meeting } & $\begin{array}{c}\text { Average During 9 } \\
\text { Meetings }\end{array}$ \\
\hline & & V-VII & IX-XI & XII-XIV & \\
\hline 1 & Attention & 81.2 & 82.9 & 85.6 & 83.23 \\
\hline 2 & Asking & 84.19 & 84.2 & 86.5 & 84.96 \\
\hline 3 & Answer the Question & 82.2 & 83.5 & 92.5 & 86.07 \\
\hline 4 & Discussion & 85.5 & 90.5 & 95.2 & 90.40 \\
\hline 5 & Take notes & 82 & 85 & 86 & 84.33 \\
\hline 6 & Doing Task & 85.7 & 86.9 & 90.7 & 87.77 \\
\hline 7. & Careful & 83.95 & 84.9 & 85.2 & 84.68 \\
\hline 8. & Discipline & 81.4 & 85.7 & 90.2 & 85.77 \\
\hline 9. & Responsible & 79.9 & 86.2 & 90.5 & 85.53 \\
\hline & Average & 82.89 & 85.53 & 89.16 & 85.86 \\
\hline
\end{tabular}

Based on Table 4, it can be concluded that the results of the analysis of student learning activities obtained an average value in the experimental class with Projectbased Learning model of 85.86 , based on the table included in the criteria of very active. In the experimental class which uses a project-based learning model, it is known that the highest learning activities of students are discussing and doing assignments. In the experimental class discussion is a student activity where students can work with groups, remind each other and no one works individually. This discussion activity is carried out during the core activities of the teaching and learning process. The discussion activity was carried out in all Project-based Learning model activities, starting from giving questions, designing project planning, arranging schedules to testing project results.

The results of student responses about the application of the Project-based Learning model can be shown in the following Table 5:

Based on student responses, it was seen that students gave a positive response to the implementation of the problem based Learning model. Based on Table 5 above, it can be explained that students' perceptions of project-based learning models are very 
TABLE 5: Student response with ‘Project-based Learning' Model.

\begin{tabular}{l|l} 
No. & Question \\
1. & $\begin{array}{l}\text { Student perceptions of the } \\
\text { project-based learning model } \\
\text { (effectively used in Innovative II } \\
\text { learning) }\end{array}$ \\
2. & $\begin{array}{l}\text { Motivation of students with the } \\
\text { existence of a project-based } \\
\text { learning model }\end{array}$ \\
3. & $\begin{array}{l}\text { Students' understanding of the } \\
\text { material with the Project-based } \\
\text { Learning model }\end{array}$ \\
4. & $\begin{array}{l}\text { Student activities during } \\
\text { Project-based Learning are ongoing } \\
\text { (independent, enthusiastic, } \\
\text { responsible, cooperative, } \\
\text { enthusiastic) }\end{array}$ \\
\hline 5. & $\begin{array}{l}\text { Benefits of applying Project-based } \\
\text { Learning Models (enhancing the } \\
\text { ability to think critically, gain } \\
\text { experience contextually) }\end{array}$ \\
\hline
\end{tabular}

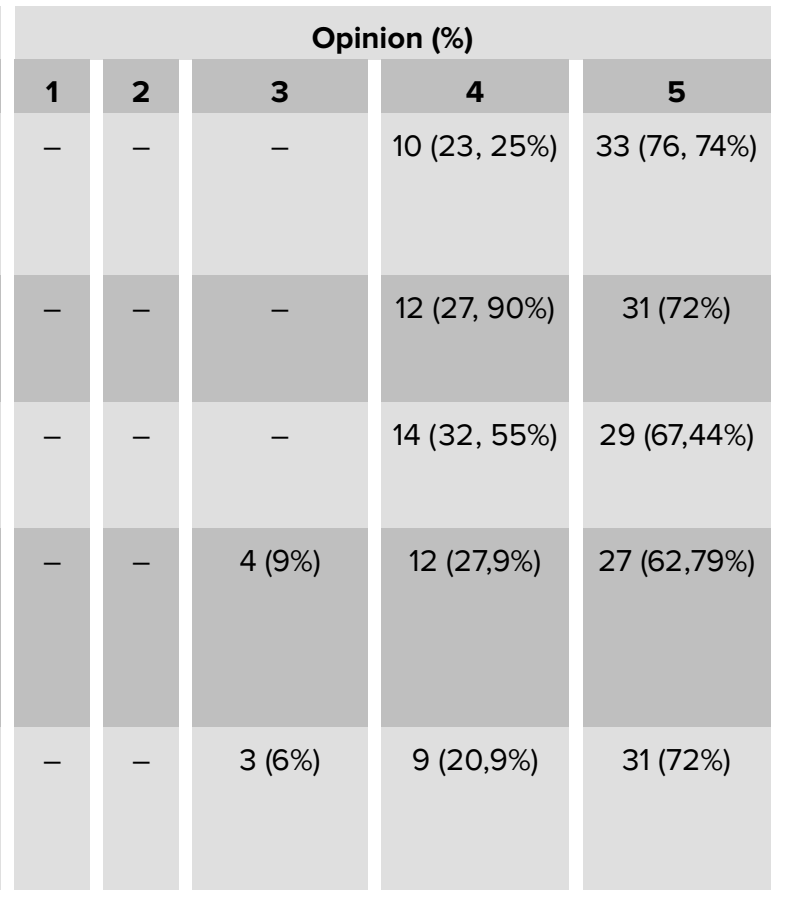

positive. There were 10 students (25\%) answering agreed and the remaining 30 students (75\%) answered strongly agreed. It can be concluded that the problem based learning model is very effective to be used in innovative learning courses.

\subsection{Research results of control classes (Conventional Learning Models)}

Conventional Learning Model in this case is a direct learning model implemented in class B students of 2015 totaling 40 students in the Innovative Learning course for 9 weeks (9 meetings). Because the learning model used is different, the syntax is different. For the control class that uses direct learning models, students are not given the task to conduct teacher observations at school. Students listen to lecturers' explanations during teaching and are given the task to analyze the cases of the application of the learning model in the research journal. Based on the case, students design learning models and practice in class.

To find out cognitive learning outcomes, the UAS questions are given the same as the questions tested in the Project-based Learning model. The following is Table 6 which explains student learning outcomes with the application of Conventional Learning Models 
TABLE 6: UAS Learning Outcomes of students with Conventional Learning Models.

\begin{tabular}{|l|l|c|c|c|}
\hline No. & Category & Value & $\begin{array}{c}\text { No. of } \\
\text { Students }\end{array}$ & $\%$ \\
\hline 1 & Very Good & $(85-100)$ & 2 & $5 \%$ \\
\hline 2 & Good & $(80-84.99)$ & 10 & $25 \%$ \\
\hline 3 & Enough & $(70-79.99)$ & 25 & $62,5 \%$ \\
\hline 4 & Low & $(50-69.99)$ & 3 & $7,5 \%$ \\
\hline 5 & Very Low & $(0-49.99)$ & - & \\
\hline
\end{tabular}

Based on Table 6 above, it was found that students get grades in the category of very high, high, sufficient, and low. No one gets very low scores.

The following is Table 7 which shows the total learning outcomes starting from the assignment value, participation, UTS, and UAS.

TABLE 7: Student Learning Outcomes With Conventional Learning Models.

\begin{tabular}{|c|c|c|c|}
\hline No. & Category & $\begin{array}{c}\text { College } \\
\text { Student }\end{array}$ & Percentage \\
\hline 1 & A (85-100) & 1 & $2.5 \%$ \\
\hline 2 & A- (80-84.99) & 10 & $25 \%$ \\
\hline 3 & B+ (75-79.99) & 20 & $50 \%$ \\
\hline 4 & B (70-74.99) & 7 & $17.5 \%$ \\
\hline 5 & B- (65-69.99) & 2 & $5 \%$ \\
\hline 6 & C+ (60-64.99) & - & \\
\hline & Total & 40 & $100 \%$ \\
\hline
\end{tabular}

Based on Table 7 above, it can be concluded that the value of students get $A$ (as many as 1 student) and $A$ - (10 students), and the rest get $B+(20$ people), $B$ (7 people) and $B-$ (2 people). It can be concluded that conventional learning models, cognitive learning outcomes are lower than learning outcomes by using Project-based Learning models.

While the value of student learning activities by applying the Project-based Learning model can be shown in the following Table 8:

Based on Table 8, the average score in the control class with conventional learning model is 81.32 , based on the table included in the active criteria but the value is still below the experimental class using a project-based learning model.

The results of student responses about the application of Conventional learning models can be shown in the following Table 9:

Based on the table of student responses to conventional learning models it appears that students respond with varied answers. There are differences in student responses between conventional learning models and Project-based Learning models. Seen on 
TABLE 8: Student Learning Activities using Conventional Learning Models.

\begin{tabular}{|l|l|}
\hline No. & $\begin{array}{l}\text { Learning Activity } \\
\text { Indicator }\end{array}$ \\
\hline 1 & Memperhatikan \\
\hline 2 & Bertanya \\
\hline 3 & Menjawab Pertanyaan \\
\hline 4 & Berdiskusi \\
\hline 5 & Mencatat \\
\hline 6 & Mengerjakan tugas \\
\hline 7. & Teliti \\
\hline 8. & Disiplin \\
\hline & Tanggung Jawab \\
\hline
\end{tabular}

\begin{tabular}{|c|c|c|}
\hline \multicolumn{3}{|c|}{ Experiment Class Meeting } \\
\hline V-VII & IX-XI & XII-XIV \\
\hline 75.5 & 76.8 & 80.4 \\
\hline 78.5 & 80.2 & 82.6 \\
\hline 80.2 & 81.5 & 80.5 \\
\hline 80.5 & 78.5 & 83.6 \\
\hline 85 & 86 & 84 \\
\hline 82.8 & 85.2 & 87.3 \\
\hline 79.2 & 80.4 & 79.9 \\
\hline 79.8 & 81.5 & 83.2 \\
\hline 80.2 & 79.4 & 82.9 \\
\hline 80.19 & 81.06 & 82.71 \\
\hline
\end{tabular}

\begin{tabular}{|c|}
\hline $\begin{array}{c}\text { Average During } 9 \\
\text { Meetings }\end{array}$ \\
\hline 77.57 \\
\hline 80.43 \\
80.73 \\
80.87 \\
85.00 \\
85.10 \\
79.83 \\
81.50 \\
80.83 \\
81.32 \\
\hline
\end{tabular}

TABLE 9: Students' responses to Conventional Learning Models.

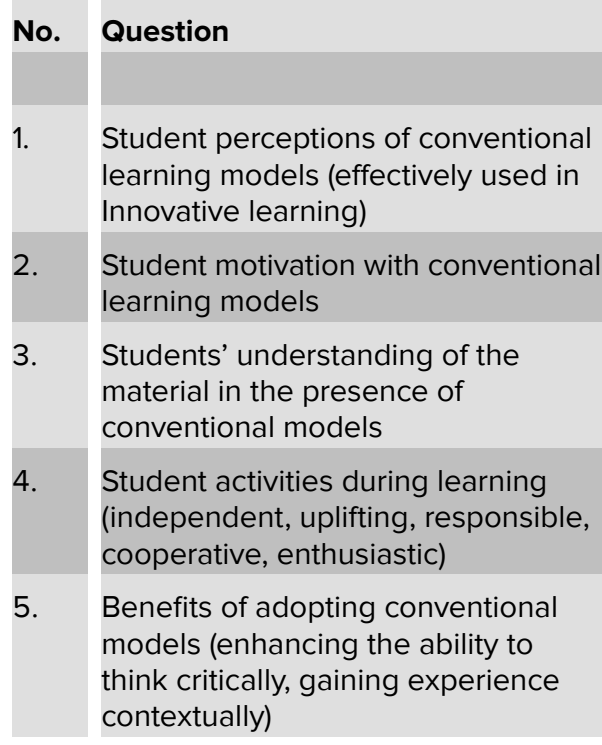

\begin{tabular}{|c|c|c|c|c|}
\hline \multicolumn{5}{|c|}{ Opinion (\%) } \\
\hline STS & TS & CS & S & SS \\
\hline 2 & 15 & 15 & 5 & 3 \\
\hline $5 \%$ & $37.5 \%$ & $37.5 \%$ & $12.5 \%$ & $7.5 \%$ \\
\hline & & & & \\
\hline & 15 & 20 & 2 & 3 \\
\hline & $37.5 \%$ & $50 \%$ & $5 \%$ & $7.5 \%$ \\
\hline & 12 & 18 & 88 & 2 \\
\hline & $30 \%$ & $45 \%$ & $220 \%$ & $5 \%$ \\
\hline 2 & 10 & 21 & 7 & - \\
\hline $5 \%$ & $25 \%$ & $52.5 \%$ & $17.5 \%$ & \\
\hline 11 & 21 & 9 & 2 & - \\
\hline $25.58 \%$ & 348.8 & $20.9 \%$ & $4 \%$ & \\
\hline & & & & \\
\hline
\end{tabular}

student perceptions about conventional learning models, which answer effectively and very effectively only 8 students, the rest answered quite effectively and less effectively. Meanwhile, the response of students using the Project-based Learning model agreed and strongly agreed. This shows that the Project-based Learning model is effective to use rather than conventional learning models.

\subsection{Discussion}

Based on the results of the data analysis, it is known that the Project-Based Learning Model can provide a new nuance for students who have never obtained this model 
before. Project work contains complex tasks based on very challenging statements and problems, and requires students to design, solve problems, make decisions, conduct investigative activities, and provide opportunities for students to work independently and in groups.

Project-based learning model uses syntax in learning, as mentioned by The George Lucas Educational Foundation which consists of 6 learning steps, namely:

1. Essential questions

2. Planning rules for project work

3. Make an activity schedule,

4. Monitor the development of peseta students

5. Assessment of the work of students

6. Evaluate the learning experience of students.

Whereas direct learning model by Arends (2013) is a learning model specifically designed to support student learning processes related to well-structured declarative knowledge and procedural knowledge, it can be taught with a stepwise step-by-step activity pattern. The syntax in the direct learning model is as follows:

1. Delivering goals and preparing students

2. Present and demonstrate knowledge or skills

3. Guiding training

4. Check understanding and feedback

5. Provide advanced training and application opportunities

The syntax of Project-based Learning model above becomes a guideline in the learning process in the experimental class, while the direct learning model syntax is a guideline in the control class learning process.

In the Project-based Learning model, students are given the task of plunging into the field. With the contextual assignment of projects, student activities and learning outcomes are better than the control class. Maximum activity, good teamwork can be observed by researchers. Students in groups try to develop learning scenarios that are appropriate for the subject matter that has been taught in the classroom. The results of the report are presented and practiced in class. During designing the learning model 
design, the ability of students to design learning scenarios in accordance with the RPP is also getting better each meeting. Students look increasingly critical in analyzing learning models, high teamwork, responsibility for tasks in accordance with their respective job descriptions seen in class. After completing the design monitored by lecturers in the classroom, students present the design results by practicing to become a classroom teacher with the maximum. Learning activities, especially discussions, have increased, as evidenced by the average discussion value of 90.40 .

The cognitive ability of the experimental class students is better than the control class. In the experimental class, students' UAS learning outcomes were classified as very high $(A)$ and high $(A-)$, only a few with enough categories $(B+)$. There is no student score in the low and very low categories. Meanwhile the learning outcomes of the control category with the most categories are enough values $(B+)$, high $(A-)$, low $(C+$ down), and very high (A). The UAS questions tested in the two classes studied were the same problem.

At the end of the semester exam the Innovative Learning II course, students are asked to design a learning model that is appropriate to the case that has been given. Based on the learning outcomes of the experimental class, it was found that 9 students got very high grades (85-100) with very good categories, 28 students got high grades (80-84.99) with good categories and the remaining 6 students got quite high scores (75- 79.99). This shows that the experimental class treated with project learning models is better than the control class given conventional learning models.

Meanwhile, the total value of the overall learning outcomes (the final value of Participation, Task, UTS, and UAS) for the experimental class gets a higher value than the control class. This is evident in the table of the experimental class with the highest value, namely $A-$, while the control class with the highest value is $B+$.

The assessment of student activity is also positive for the Project-based Learning model, with an average score of 85.86. Meanwhile, the assessment of student activity in the control class with an average value below that is equal to 81.32.

Based on the results of the above research, it can be explained that this research is in line with the theory that the application of the Project-based Learning model has several benefits as conveyed by Moursound et al. (in Sumarmi, 2012) as follows:

1. Increase motivation. Students report that learning in projects is more fun than other curriculum components. Written reports about the project many say that students become more diligent to the limit. 
2. Improve problem solving skills. Research on the development of high-level cognitive skills in students emphasizes the need for student involvement in problem solving and learning tasks, especially how to find and solve problems.

3. Increase collaboration. New and controversial cognitive theories affirm that learning is a social phenomenon, and students will learn more in a collaborative environment (Vygotsky, 1978; Davidof, 1995). The importance of group work in projects requires students to develop and practice communication skills. Cooperative work group, learner evaluation, online information exchange are collaborative aspects of a project.

4. Improve resource management skills. Project-based learning that is well implemented will provide students with learning and practice in organizing projects, making time allocations, and other resources such as equipment to complete tasks.

\section{Conclusion}

Based on the results of the research and discussion, the following data can be concluded:

1. The Project-based Learning model is effective for students taking Innovative Learning courses. Project-based Learning model in achieving cognitive, affective and psychomotor learning outcomes is more effective than conventional methods in innovative learning courses

2. Student learning activities in the Project-based Learning model are more effective than conventional learning models.

3. Student responses with the existence of a positive Project-based Learning model

\section{Acknowledgment}

The authors would like to thank the lecturers and students at the Faculty of Economics, State University of Surabaya, who have helped and provided advice and support for this research. 


\section{References}

[1] Eason, G., Noble, B., and Sneddon, I. N. (April 1955). On certain integrals of LipschitzHankel type involving products of Bessel functions. Philosophical Transactions of the Royal Society A, vol. A247, pp. 529-551.

[2] Grant, M. (April 2009). Understanding projects in projectbased learning: A student's perspective. Paper presented at Annual Meeting of the American Educational Research Association, San Diego, CA.

[3] Markham, T. (2003). Project-based Learning Handbook (second edition). Novato, CA: Buck Institute for Education.

[4] Boss, S. (2013). Project Based Learning: Learning forum puts PBL teachers on world stage. Retrieved from: http://www.edutopia.org/blog/world-stage-project-learningsuzie-boss

[5] Wellham, H. (2013). Project-based learning: How can you make it work in your school? The Guardian. Retrieved from: http://www.theguardian.com/teachernetwork/teacherblog/2013/nov/30/project-based-learning-live-chat

[6] Chen, L. (2004). Cooperative Project-based learning and students's learning styles on web page development. Journal of Educational Technology Systems, vol. 32, no. 4, pp. 363-375.

[7] Efstratia, D. (2014). Experiential education through project based learning. Procedia - Social and Behavioral Sciences, vol. 152, pp. 1256-1260.

[8] Ergül, N. R. and Kargin, E. K. (2014). The effect of project based learning on students' science success. Procedia - Social and Behavioral Sciences, vol. 136, pp. 537-541.

[9] Sumarmi. (2012). Model-Model Pembelajaran Geografi. Malang: Aditya Media Publishing.

[10] Arends, R. I. (2013). Belajar Untuk Mengajar, Learning to Teach. Jakarta: Salemba Humanika

[11] Vygotsky, L. S. (1978). Mind in society. M. Cole, V. John-Steiner, S. Scribner, and E. Souberman (eds.) The Development of Higher Psychological Processes. Cambridge, Massachusetts: Harvard University Press.

[12] Davidov, V. V. (1995). The influence of L. S. Vygotsky on education theory, research and practice, Stephen T. Kerr (Trans.). Educational Researcher, vol. 24, pp. 12-21. 